\title{
Perkembangan Otak dan Kognitif Anak: Peran Penting Sistem Imun pada Usia Dini
}

\author{
Ahmad Suryawan, Anang Endaryanto \\ Departemen Ilmu Kesehatan Anak Fakultas Kedokteran Universitas Airlangga - Rumah Sakit Umum Daerah Dr. Soetomo, Surabaya
}

\begin{abstract}
Abstrak
Perkembangan kognitif anak merupakan cerminan dari kompleksitas kerja sirkuit otak yang terbentuk sejak usia dini dan harus melewati periode kriitis pada tahun-tahun pertama awal kehidupan anak. Semakin kompleks sirkuit otak yang terbentuk, maka semakin besar kapasitas anak untuk belajar mengembangkan kemampuan kognitif. Saat ini berbagai studi mengkaitkan antara perkembangan otak dengan perkembangan sistem imun anak pada usia dini. Sistem imun selama ini lebih dikenal peranannya dalam sistem pertahanan tubuh untuk melawan organisme patogen, ternyata terbukti juga mempunyai peran khusus dalam proses perkembangan otak, baik dalam kondisi yang normal atau sehat, maupun pada kondisi patologis. Proses perkembangan otak dan sistem imun melibatkan berbagai sel dan molekul-molekul mediator yang sama, seperti protein dan sitokin. Keterkaitan perkembangan otak dan sistem imun terjadi secara dua arah dengan konsep mekanisme yang terprogram sejak usia dini, dimana aktivasi di usia dini akan berdampak jangka panjang terhadap kedua sistem tersebut. Berbagai studi saat ini juga membuktikan bahwa mikrobiota saluran cerna juga berperan khusus dalam sistem imun dan perkembangan otak. Memahami aktivasi sistem imun selama periode kritis perkembangan otak anak merupakan langkah yang strategis untuk dapat mengungkap patogenesis berbagai gangguan perkembangan, perilaku, dan kognitif pada anak dan juga terhadap berbagai cara dan metode terapi di masa depan. Sari Pediatri 2021;23(4):279-84
\end{abstract}

Kata kunci: perkembangan otak, anak, kognitif, sistem imun

\section{Child's Brain and Cognitive Development: The Important Role of the Immune System in Early Childhood}

Ahmad Suryawan, Anang Endaryanto

\begin{abstract}
Child's cognitive development is a reflection of brain circuits activities that are developed since an early age. The more complex brain circuits that are formed, the greater child's capacity to develop their cognitive abilities. Studies linking brain development to the development of the child's immune system at an early age. The immune system, which has been better known for its role in the body's defense system, has also been shown to have a special role in the brain development. The brain development and the immune system also involve the same various cells and mediator molecules, such as proteins and cytokines. The linkage of brain development and the immune system occurs in two directions with the concept of an early programming mechanism, which activation at an early age will have a long-term impact on both systems. Recent studies also revealed that gastrointestinal microbiota also plays a special role in the immune system and brain development. Understanding the development and activation of the immune system during a critical period of brain development in children is a strategic step to uncover pathogenesis of various developmental, behavioral, and cognitive disorders in children and also the various ways and methods of treatment in the future. Sari Pediatri 2021;23(4):279-84
\end{abstract}

Keywords: brain development, child, cognitive, immune system

Alamat korespondensi: Ahmad Suryawan. Departemen Ilmu Kesehatan Anak Fakultas Kedokteran Universitas Airlangga - Rumah Sakit Umum Daerah Dr. Soetomo. Jl. Mayjend Prof Dr. Moestopo No 6-8, Surabaya, Jawa Timur. Email: abmad.suryawan@fk.unair.ac.id 
S istem otak dan sistem imun dahulu dipelajari sebagai dua sistem yang terpisah, tetapi saat ini diketahui merupakan dua sistem yang berfungsi dengan cara saling berbagi dan sangat terorganisir. Sistem imun ternyata tidak hanya berperan sebatas pada sistem pertahanan tubuh, tetapi juga mempunyai peran khusus dalam proses perkembangan otak, baik dalam kondisi yang normal atau sehat, maupun pada kondisi patologis. Demikian pula sebaliknya, berbagai neurotransmitter yang berperan dalam perkembangan otak dan kognitif, ternyata juga mempunyai peran dalam perkembangan sistem imun. ${ }^{1}$ Keterkaitan antara kedua sistem tersebut bahkan relatif tidak diduga sebelumnya, dan disinyalir mempunyai dampak terhadap patogenesis tumbuh kembang anak jangka panjang, seperti kemampuan kognitif dan perilaku. ${ }^{1}$

Otak merupakan organ dimana sistem imun mempunyai peran khusus. Berbagai molekul imunitas bawaan dan imunitas didapat, juga diekspresikan di otak dan memainkan peran penting dalam perkembangan otak. ${ }^{2}$ Pemahaman tentang komunikasi dua arah antara otak dan sistem imun mempunyai implikasi terhadap pengetahuan tentang patogenesis, cara dan metode tatalaksana dari berbagai gangguan perkembangan, gangguan perilaku dan kognitif pada anak di masa depan.

\section{Perkembangan otak dan sistem imun pada awal kehidupan}

Perkembangan otak diawali dengan pembentukan sel progenitor neuron, yang akan mengalami diferensiasi, dan migrasi untuk membentuk subplate korteks. Akson dan percabangan dendrit membentuk koneksi sinaptik (sinaptogenesis) yang berfungsi jangka panjang dalam pembentukan kemampuan anak. Sinaps yang terbentuk, akan mengalami eliminasi sekitar $50 \%$ pada masa setelah lahir dan selama masa transisi dari periode anak atau remaja menuju masa dewasa. ${ }^{3,4}$ Sementara itu, perkembangan sistem imun melibatkan lebih dari 1600 gen yang kesemuanya sangat penting untuk pertahanan hidup dalam suasana lingkungan yang rentan. Anak lahir dengan kondisi sistem imun bawaan dan adaptif yang masih imatur, dan akan berkembang semakin matur seiring dengan pertambahan usia, kemudian mengalami penurunan pada masa lanjut usia.,
Pada awal kehidupan, kedua sistem tersebut berkembang dengan tahapan yang selalu hampir bersamaan. Ketika otak memulai neurogenesis, pada saat yang bersamaan pada sisten imun mulai terjadi hematopoiesis. Ketika otak memasuki tahap migrasi neuron, pada saat bersamaan sistem imun juga memasuki tahap migrasi sel-sel imun dan ekspansi sel progenitor. Ketika otak memasuki tahap sinaptogenesis dan gliogenesis, pada saat yang bersamaan terjadi kolonisasi sel-sel imun pada sistem imun. Dan, ketika pada otak terjadi proses mielinisasi, pada sistem imun terjadi proses maturasi dari imunitas bawaan dan adaptif. Kesamaan waktu dalam berbagai proses tersebut menunjukkan bahwa interaksi dua arah antara otak dan sistem imun telah mulai terjadi sejak awal kehidupan. ${ }^{7}$

\section{Komunikasi dua arah antara otak dan sistem imun}

Sitokin secara klasik digambarkan sebagai molekul utama dalam regulasi komunikasi antar sel-sel imun, sedangkan neurotransmiter digambarkan sebagai molekul mediator untuk interaksi antar neuron atau antara glia dengan neuron. Regulasi sel-sel imun dalam perkembangan otak terjadi pada banyak aspek, yang terjadi sejak mulai tahap awal perkembangan otak, seperti pembentukan sinaps, proses eliminasi sinaps, hingga regulasi plastisitas neuron. Interaksi antara sel imun dan otak tersebut terjadi secara dua arah. ${ }^{8}$ Saat ini diketahui bahwa sel-sel imun tidak hanya mampu mengekspresikan reseptor-reseptor neurotransmiter saja, tetapi juga mempunyai kapasitas untuk menyintesis dan menyimpan neurotransmiter di dalam kompartemen intraseluler, yang dapat sewaktu-waktu dilepaskan bila mendapatkan rangsangan spesifik. Sebaliknya, sel-sel otak juga diketahui dapat memproduksi berbagai molekul sitokin. Dengan demikian dapat dikatakan bahwa sel-sel sistem imun dapat berkomunikasi melalui berbagai neurotransmiter, dan sel-sel otak dapat berkomunikasi dengan adanya sitokin sebagai mediator. ${ }^{9}$

Sekitar $80 \%$ sel imun di dalam otak adalah mikroglia, selain sel lainnya, seperti mioloid, monosit/ makrofag, sel dendrit, sel T, sel B, dan Sel NK. ${ }^{11}$ Peran sel $T$ dalam berbagai proses otak untuk kemampuan belajar spasial, memori, perilaku-emosi dan respons stres telah terbukti dalam studi eksperimental. ${ }^{2}$ Berbagai sitokin yang selama ini lebih dikenal sebagai mediator 
perifer dari reaksi inflamasi dan regulasi respon imun kompleks untuk melawan infeksi dan injury, ternyata juga diketahui dapat disintesis di dalam otak baik oleh sel glia maupun neuron.?

Salah satu contoh proses fisiologis regulasi sitokin di dalam otak adalah mekanisme LTP (long term potentiation) hipokampus, yakni sebuah mekanisme yang ditandai dengan peningkatan transmisi sinaptik berkesinambungan pada stimulasi frekuensi tinggi, yang merupakan salah satu dasar proses belajar dan penyimpanan memori dalam otak. ${ }^{10}$ Pada studi eksperimental terbukti mekanisme LTP diregulasi oleh IL-1 $\beta$ yang diproduksi sel glia dengan mediator neuregulin-1 (Nrg-1) yang dilepas oleh neuron pre-sinaptik. ${ }^{11}$ Blokade pada reseptor IL-1 $\beta$ akan menghambat kerja mekanisme LTP, ${ }^{12}$ dan sehingga tidak adanya sinyaling IL-1 $\beta$ di dalam otak akan menurunkan proses belajar dan memori. ${ }^{10}$

Sitokin lain yang berperan dalam regulasi perkembangan dan fungsi otak adalah sitokin IL-6, yang berperan dalam mengkonsolidasi penekanan LTP. Studi eksperimental membuktikan bahwa ekspresi IL-6 di hipokampus akan menekan LTP yang berakibat menurunnya kemampuan belajar dan memori pada otak. ${ }^{13}$ Contoh sitokin yang bekerja sebagai modulator antar sel otak adalah TNF $\alpha$, yang diproduksi oleh sel-sel glia untuk memperkuat efek sinaptik dengan meningkatkan ekpresi reseptor AMPA glutamat ionotropik pada neuron-neuron post-synaptic. ${ }^{14}$ Berbagai mediator yang diproduksi oleh sel otak mempunyai fungsi khusus dalam sistem imun, seperti Protocadherin (Pcdh), Eph/Ephrin dan famili Semaphorin, disinyalir juga mempunyai peran sebagai molekul imun-modulator. ${ }^{2}$ Semaphorins, molekul utama pemandu akson saraf, juga terlibat dalam berbagai fase respons imun fisiologis dan patologis yang terkait dengan berbagai gangguan imun seperti: rheumatoid arthritis, sistemic lupus erythematosus, dan sistemic sklerosis. ${ }^{15}$

Keterkaitan antara perkembangan kognitif dan disregulasi sistem imun

Disregulasi sistem imun berkaitan dengan perkembangan kognitif dan perilaku anak, dan sebaliknya, misalnya, fenotip alergi pada masa bayi berhubungan dengan perkembangan kecerdasan dan perilaku anak pada usia selanjutnya. Apabila anak pada saat usia 12 bulan mengalami alergi makanan dan atau eksema, ternyata pada usia 18 bulan mengalami penurunan skor motorik $(\mathrm{p}=0,016)$ dan problem perilaku internalisasi $(\mathrm{p}=0,010) .{ }^{16}$ Sebaliknya, status perkembangan anak di usia 4 tahun mempunyai hubungan negatif dengan terjadinya atopi pada usia 6 tahun, dengan risiko relatif sebesar 3,06 (95\% CI: $1,30-7,24)$ untuk skala kognitif umum. ${ }^{17}$

Disregulasi sistem imun dalam bentuk infeksi juga berhubungan dengan perkembangan anak. Infeksi enterovirus (EV) pada anak berkaitan dengan ganguan bicara-bahasa $(\mathrm{HR}=1,14,95 \% \mathrm{CI}: 1,06-1,22)$, baik pada komunitas anak yang pernah mengalami perawatan di rumah sakit (HR=1,12, 95\% CI: 1,031,21) karena infeksi $E V$ ataupun yang tidak dirawat di rumah sakit (HR=1,26, 95\% CI: 1,10-1,45). ${ }^{18}$ Infeksi Mycoplasma pneumoniae juga berhubungan signifikan dengan insiden gangguan bahasa $(\mathrm{HR}=1,49,95 \% \mathrm{CI}$ : $1,23 \pm 1,80] .{ }^{19}$ Pada anak dan remaja dengan infeksi HIV, ternyata skor Pediatric Symptom Checklist (PSC), sebuah instrumen untuk mengukur adanya disfungsi psikososial, berhubungan signifikan dengan angka proporsi kegagalan virologis. ${ }^{20}$

\section{Perkembangan otak dan aktivasi sistem imun pada usia dini}

Otak dan sistem imun saling berkomunikasi pada kondisi sehat maupun saat kondisi patologis. Stresor yang terjadi pada usia dini, pada masa intra-uterin atau perinatal, dapat berakibat disregulasi neuroimun dan perkembangan otak anak jangka panjang, termasuk gangguan kognitif dan perilaku. Terdapat dua kemungkinan jalur aktivasi imun di masa usia dini akan memengaruhi perkembangan perilaku, proses belajar dan penyimpanan memori di otak, yaitu (1) mengubah atau mengganggu perkembangan jalur persarafan untuk belajar dan memori, atau (2) memprogram ulang fungsi imun pada saat dewasa, yang pada akhirnya secara tidak langsung merusak proses persarafan yang penting untuk kognitif. $^{21}$

\section{Aktivasi imun pada masa in-utero}

Studi epidemiologi menunjukkan adanya keterkatitan antara infeksi maternal dengan onset beberapa gangguan perkembangan, seperti autism spectrum disorders (ASD) dan palsi serebral, yang membuktikan adanya hubungan antara sistem imun dengan perkembangan otak. ${ }^{7}$ Konsentrasi IL-6 dan CRP pada kehamilan trimester-3 
berhubungan dengan konektivitas fungsional otak anak di masa neonatal dan perkembangan perilaku dan kognitif pada masa usia pra-sekolah. ${ }^{22}$ Peningkatan konsentrasi IFN- $\gamma$, IL-4, dan IL-5 dalam serum maternal selama pertengahan kehamilan berhubungan signifikan dengan peningkatan risiko sebesar $50 \%$ untuk mengalami ASD. ${ }^{23}$

\section{Ativasi imun pada masa perinatal}

Pada bayi prematur, peningkatan kadar protein inflamasi, seperti ICAM-3, IL-6, TNF-RI, IL-8, ICAM3, VEGF-R1, dan VEGF-R2, pada dua minggu pertama setelah lahir berhubungan dengan problem atensi pada saat anak berusia 2 tahun. ${ }^{24}$ Di samping itu juga, peningkatan konsentrasi CRP,IL-1b, IL-6, dan IL-8 pada minggu ke-3 dan ke-4 setelah lahir berhubungan dengan peningkatan risiko untuk mengalami mikrosefali dan skor perkembangan yang rendah pada saat usia 2 tahun. ${ }^{25}$ Peningkatan kadar protein CRP, TNF-a, IL-8, ICAM-1, dan erythropoietin pada 1 bulan awal setelah lahir berhubungan dengan skor IQ yang rendah (ORs: 2.0-2.3), dan gangguan kognitif (ORs: 2.1-3.6) pada saat anak berusia 10 tahun. ${ }^{26}$

\section{Aktivasi imun pada masa anak usia dini}

Marker inflamasi pada satu tahun awal kehidupan berhubungan signifikan dengan luaran perkembangan anak. Peningkatan konsentrasi sitokin pro-inflamasi berhubungan dengan skor kemampuan motorik yang rendah. Sementara itu, peningkatan konsentrasi sitokin Th-2, seperti IL-4, berhubungan dengan peningkatan skor kognitif. Peningkatan kadar protein yang terkait inflamasi (ORM1, a-1-antichymotrypsin, reticulocalbin-1, dan tiga komponen dari kaskade komplemen) berhubungan dengan skor kognitif yang rendah. Bukti ini menegaskan bahwa marker inflamasi mempunyai nilai prognostik dan potensial digunakan sebagai terapi berbasis imun untuk mencegah gangguan perkembangan pada anak yang berisiko tinggi. ${ }^{27}$

Peningkatan konsentrasi protein terkait inflamasi (CRP, sCD14, IL-1b, and IL-6) pada satu tahun awal kehidupan berhubungan dengan skor perkembangan (kognitif, motorik, bahasa, dan sosial-emosi) yang rendah pada saat anak berusia 2 tahun. ${ }^{28}$ Paparan infeksi pada usia dini (terutama pada usia 1 tahun pertama di awal kehidupan) berhubungan signifikan dengan skor IQ yang rendah pada saat dewasa (usia 18 tahun) (MD: $-1,61 ; 95 \% \mathrm{CI},-1,74-1,47) .{ }^{29}$

\section{Peran mikrobiota saluran cerna dalam perkembangan otak}

Studi tentang keterkaitan antara perkembangan otak anak dan sistem imun pada usia dini juga banyak dihubungkan dengan mikrobiota saluran cerna, yang dikenal dengan istilah "Gut microbiota - immune brain axis". ${ }^{30}$ Meskipun mekanismenya masih belum sepenuhnya dipahami dan terus diteliti, para ahli sepakat bahwa peran mikrobiota dalam perkembangan otak terjadi secara dua arah dengan melibatkan jalur saraf, jalur endokrin atau hormonal, jalur imun, dan jalur metabolik. $^{31}$

Keterkaitan antara mikrobiota saluran cerna pada usia dini dengan perkembangan otak dan kognitif anak mulai dibuktikan dari beberapa studi klinis. Studi Isolauri dkk, ${ }^{32}$ tahun 2014 membuktikan bahwa pada kelompok yang mengalami gangguan perilaku ADHD dan/atau Asperger Syndrome pada saat usia 13 tahun, ternyata ketika berusia 6 bulan pertama mempunyai kolonisasi mikrobiota yang lebih sedikit dibandingkan anak sehat yang tidak mengalami gangguan perilaku (Bifidobacterium sp, $\mathrm{p}=0,03$; Bifidobacterium longum, $\mathrm{p}=0,045)$. Komposisi jenis mikrobiota saluran cerna pada anak berusia 1 tahun mempunyai nilai prediktor untuk performa kognitif anak saat berusia 2 tahun, terutama kemampuan bicara-bahasa, yang diukur dengan skor Mullen. ${ }^{33}$

Saat ini, studi "Gut microbiota - immune - brain axis" mulai banyak menyentuh aspek penelitian tentang strain mikrobiota spesifik yang mungkin akan dikembangkan sebagai salah satu bentuk terapi mikrobiologi di masa mendatang, ${ }^{34}$ termasuk untuk perkembangan otak, kognitif, dan perilaku anak. Beberapa studi tersebut, misalnya, berdasar studi klinis maupun eksperimental, pemberian strain probiotik Bifidobacteria breve M-16V pada bayi atau anak terbukti mempunyai dampak yang multi sistem, ${ }^{35}$ antara lain, optimalisasi kolonisasi bifidobacteria saluran cerna bayi prematur ${ }^{36}$ dan BBLR, ${ }^{37}$ mencegah dan mengurangi derajat beratnya dermatitis atopik, alergi makanan, rinitis alergika, dan asma ${ }^{38}$ dan 
juga ketika diberikan dalam bentuk sebuah regimen campuran dengan prebiotik GOS/FOS. ${ }^{39}$ Selain itu, karena kemampuannya dalam memproduksi metabolit triptofan, ${ }^{40}$ maka tidak menutup kemungkinan studi tentang strain ini akan menyentuh ranah perkembangan otak dan perilaku anak.

\section{Kesimpulan}

Gabungan teori aktivasi sistem imun di usia dini (early programming theory) dan teori "Gut microbiota immune - brain axis" akan memprogram perkembangan kognitif anak di masa depan. Gabungan kedua teori tersebut dapat diibaratkan dengan sebuah bangunan segitiga dengan ketiga sisinya yang saling berinteraksi dua arah. Sisi pertama menghubungkan antara sistem imun dan mikrobiota saluran cerna. Sisi kedua menghubungkan antara mikrobiota saluran cerna dengan perkembangan otak. Sisi ketiga menghubungkan antara perkembangan otak dengan sistem imun. Ketiga sisi tersebut menghasilkan sistem imun optimal yang akan membentuk perkembangan otak yang optimal pula, dan sebaliknya. Perkembangan keilmuan baru ini berimplikasi terhadap pengetahuan tentang patogenesis berbagai gangguan perkembangan, gangguan perilaku dan kognitif, dan juga gangguan sistem imun pada anak. Tidak menutup kemungkinan juga akan muncul berbagai berbagai cara dan metode penanganannya di masa depan.

\section{Daftar pustaka}

1. Spichak S, Dinan TG, Cryan JF. Gut-neuroimmune interactions: the unexpected role of the immune system in brain development. Biochem (Lond) 2019;41:36-41.

2. Morimoto K, Nakajima K. Role of the Immune System in the Development of the Central Nervous System. Front Neurosci 2019;13:916.

3. de Graaf-Peters VB, Hadders-Algra M. Ontogeny of the human central nervous system: What is happening when?. Early Hum Dev 2006;82:257-66

4. Andersen SL. Trajectories of brain development: point of vulnerability or window of opportunity?. Neurosci Biobehav Rev 2003;27:3-18.

5. Simon AK, Hollander GA, McMichael A. Evolution of the immune system in humans from infancy to old age. Proc $R$ Soc B 2015;282: 20143085.
6. Dowling DJ, Levy O. Ontogeny of Early Life Immunity. Trends Immunol 2014;35: 299-310.

7. Estes ML, McAllister AK. Maternal immune activation: Implications for neuropsychiatric disorders. Science 2016;353:772-7.

8. Dantzer R. Neuroimmune interactions: from the brain to the immune system and vice versa. Physiol Rev 2018;98:477-504.

9. Pacheco R, Contreras F, Prado C. Cells, molecules and mechanisms involved in the neuro-immune interaction. Dalam: Gowder, penyunting. Cell Interaction, InTech. Europe, Croatia, 2012.h.139-66.

10. Korin B, Ben-Shaanan TL, Schiller M, dkk. High-dimensional, single-cell characterization of the brain's immune compartment. Nat Neurosci 2017;20:1300-9.

11. Ren K, Dubner R. Interactions between the immune and nervous systems in pain. Nat Med 2010;16:1267-76.

12. Goshen I, Kreisel T, Ounallah-Saad H, dkk. A dual role for interleukin-1 in hippocampal-dependent memory processes. Psychoneuroendocrinol 2007;32:1106-15.

13. Besedovsky HO, del Rey A. Central and peripheral cytokines mediate immunebrain connectivity. Neurochem Res 2011;36:1-6.

14. Stellwagen D, Malenka RC. Synaptic scaling mediated by glial TNF-alpha. Nature 2006;440:1054-59.

15. Nishide M, Kumanogoh A. The role of semaphorins in immune responses and autoimmune rheumatic diseases. Nat Rev Rheumatol 2018;14:19-31.

16. Meldrum SJ, D’Vaz N, Dunstan JA, dkk. Allergic disease in the first year of life is associated with differences in subsequent neurodevelopment and behaviour. Early Hum Dev 2012;88:567-73.

17. Julvez J, Torrent M, Guxens M, Antó JM, Guerra S, Sunyer J. Neuropsychologic status at the age 4 years and atopy in a population-based birth cohort. Allergy 2009; 64:1279-85.

18. Hung TH, Chen VCH, Yang YH, dkk. Association between enterovirus infection and speech and language impairments: A nationwide population-based study. Res Dev Disabil 2018;77:76-86.

19. Tsai CS, Chen VCH, Yang YH, dkk. The association between mycoplasma pneumoniae infection and speech and language impairment: A nationwide population-based study in Taiwan. PLoS ONE 2017;12: e0180402.

20. Lowenthal ED, Marukutira T, Tshume O, Chapman J, Anabwani GM, Gross R. Prediction of HIV Virologic Failure among adolescents using the pediatric symptom checklist. AIDS Behav 2015;19:2044-8.

21. Bilbo SD, Schwarz JM. The immune system and developmental programming of brain and behavior. Front Neuroendocrinol 2012;33:267-86.

22. Spann MN, Monk C, Scheinost D, Peterson BS. Maternal immune activation during the third trimester is associated with neonatal functional connectivity of the salience network and fetal to toddler behavior. J Neurosci 2018;38:2877-86.

23. Goines PE, Croen LA, Braunschweig D, dkk. Increased midgestational IFN-g, IL-4 and IL-5 in women bearing a child with autism: A case-control study. Molecular Autism 2011;2:1-11. 
24. O'Shea TM, Joseph RM, Kuban KCK, dkk. Elevated blood levels of inflammation-related proteins are associated with an attention problem at age 24 months in extremely preterm infants. Pediatr Res 2014;75:781-7.

25. Leviton A, Allreda EN, Fichorovab RN, Kubanc K, O'Shead TM, Dammanne O. Systemic inflammation on postnatal days 21 and 28 and indicators of brain dysfunction 2 years later among children born before the 28th week of gestation. Early Hum Dev 2016;93:25-32.

26. Kuban KCK, Joseph RM, O'Shea TM, dkk. Circulating Inflammatory-associated proteins in the first month of life and cognitive impairment at age 10 years in children born extremely preterm. J Pediatr 2017;180:116-23.

27. Jiang NM, Tofail F, Moonah SN, dkk. Febrile illness and pro-inflammatory cytokines are associated with lower neurodevelopmental scores in Bangladeshi infants living in poverty. BMC Pediatr 2014;14:1-9.

28. Jiang NM, Tofail F, Ma JZ, dkk. Early life inflammation and neurodevelopmental outcome in Bangladeshi infants growing up in adversity. Am J Trop Med Hyg 2017;97:974-9.

29. Khandaker GM, Dalman C, Kappelmann N, dkk. Association of childhood infection with IQ and adult nonaffective psychosis in Swedish Men a population-based longitudinal cohort and co-relative study. JAMA Psychiatry 2018;75:356-62.

30. Wang HX, Wang YP. Gut microbiota-brain axis. Chin Med J 2016;129:2373-80.

31. Wang Y, Kasper LH. The role of microbiome in central nervous system disorders. Brain Behav Immun 2014;38:1-12.

32. Isolauri E, Partty A, Kalliomki M, Endo A, Salminen S. Early gut microbiota composition-a possible target to reduce the risk of developing neuropsychiatric disorders? FASEB J 2014;28:Supp 637.611.

33. Carlson AL, Xia K, Azcarate-Peril MA, dkk. Infant gut microbiome associated with cognitive development. Biol Psychiatry 2018;83:148-59.

34. Cionci NB, Baffoni L, Gaggìa F, Di Gioia D. Therapeutic microbiology: the role of bifidobacterium breve as food supplement for the prevention/treatment of paediatric diseases. Nutrients 2018;10:1723.

35. Wong CB, Iwabuchi N, Xiao J. Exploring the science behind bifidobacterium breve $\mathrm{M}-16 \mathrm{~V}$ in infant health. Nutrients 2019; 11:1724.

36. Patole S, Keil AD, Chang A, dkk. Effect of bifidobacterium breve $\mathrm{M}-16 \mathrm{~V}$ supplementation on fecal bifidobacteria in preterm neonates-a randomised double blind placebo controlled trial. PLoS ONE 2014;9:e89511.

37. Li Y, Shimizu T, Hosaka A, Kaneko N, Ohtsuka Y, Yamashiro Y. Effects of bifidobacterium breve supplementation on intestinal flora of low birth weight infants. Pediatr Int 2004;46:509-15.

38. Del Giudice MM, Indolfi C, Capasso M, Maiello N, Decimo F, Ciprandi G. Bifidobacterium mixture (B longum BB536, $B$ infantis M-63, B breve M-16V) treatment in children with seasonal allergic rhinitis and intermittent asthma. Ital J Pediatr 2017;43:25.

39. Van der Aa LB, Van Aalderen WMC, Heymans HAS, dkk. Synbiotics prevent asthma-like symptoms in infants with atopic dermatitis. Allergy 2011;66:170-7.

40. Sakurai T, Odamaki T, Xiao J. Production of indole-3-lactic acid by bifidobacterium strains isolated fromhuman infants. Microorganisms 2019;7:340. 